\title{
Comparative study between the hemocytometric and spectrophotometric methods for measuring the sperm concentration of young Nelore bulls
}

\author{
Estudo comparativo entre o método hematocitométrico e o uso do \\ espectrofotômetro para mensurar a concentração espermática de \\ touros jovens da raça Nelore
}

\author{
Cléber Cardeal ${ }^{1}$; Luiz Romulo Alberton ${ }^{2 *}$; André Giarola Boscarato ${ }^{3}$; Mirelly \\ Vitalina Rocha ${ }^{1}$; Lucas Giovanni Lima Marchetti ${ }^{3}$; Gustavo Guerino Macedo ${ }^{24}$; \\ Emerson Luiz Botelho Lourenço²; Leonardo Franco Martins ${ }^{2}$
}

\begin{abstract}
Determination of sperm concentration using the Neubauer chamber (hemocytometric method) is a direct method for counting cells and also the most reliable. However, the process is time-consuming rendering it the least practical method when large numbers of ejaculates need to be processed. The spectrophotometer measures sperm concentrations as optical density and its main advantages are practicality and speed. This paper aimed to compare the results between evaluators using the hemocytometric method and the spectrophotometer for measuring sperm concentrations in young Nelore bulls. In total, 73 ejaculations from 20 young Nelore bulls were collected by electroejaculation. After soundness examination, $10 \mu \mathrm{L}$ of the semen was diluted in $2 \mathrm{~mL}$ saline formaldehyde for measuring the sperm concentration per $\mathrm{mL}$ by the hemocytometric method (measured by three different evaluators) and the spectrophotometer method at $550 \mathrm{~nm}$ wavelength. No differences were detected in the results of sperm concentration measurements per $\mathrm{mL}$ among the evaluators using the hemocytometric method and the spectrophotometer $(\mathrm{P}>0.05)$. The intraclass correlation was high (0.9), showing high replicability among the evaluator measurements. These results demonstrate that measurements performed using the spectrophotometer are reliable and can substitute the hemocytometric method in future for performing sperm concentration measurements in young Nelore bulls, thus improving and standardizing the techniques used in andrology laboratories. Key words: Absorbance. Andrology. Bos indicus. Neubauer chamber. Semen.
\end{abstract}

\section{Resumo}

A determinação da concentração espermática pela câmara de Neubauer (método hematocitométrico) é um método direto para contar células, e também é o mais confiável. Entretanto, o processo é demorado, o que o torna um método menos prático quando a quantidade de ejaculados a ser processado é muito grande. O espectrofotômetro é um dispositivo que mede a concentração de espermatozoides através

\footnotetext{
${ }^{1}$ Mestres, Programa de Pós-Graduação em Ciência Animal com Ênfase em Produtos Bioativos, Campus Sede, Universidade Paranaense, UNIPAR, Umuarama, PR, Brasil. E-mail: clebercardeal_foz@hotmail.com; mirivitalina@hotmail.com

2 Profs., Programa de Pós-Graduação em Ciência Animal com Ênfase em Produtos Bioativos, Campus Sede, UNIPAR, Umuarama, PR, Brasil. E-mail: leonardomartins@prof.unipar.br; romulo@unipar.br; emerson@prof.unipar

3 Discentes, Programa de Pós-Graduação em Ciência Animal com Ênfase em Produtos Bioativos, Campos Sede, UNIPAR, Umuarama, PR, Brasil E-mail: andreboscarato@prof.unipar.br; lucasmarchetti2009@hotmail.com

4 Prof., Universidade Federal de Uberlândia, Faculdade de Medicina Veterinária, Campus Sede, UFU, Uberlândia. MG, Brasil. E-mail: gmacedo@famev.ufu.br

Author correspondence
} 
da densidade óptica, e as suas principais vantagens são a sua praticidade e sua velocidade. O objetivo deste trabalho foi comparar os resultados entre os avaliadores no método hematocitométrico e o espectrofotômetro para medir a concentração de espermatozoides no ejaculado de touros jovens da raça Nelore. Um total de 73 ejaculações de 20 touros jovens da raça Nelore foram coletados por meio de eletroejaculação. Após exame andrológico, $10 \mu \mathrm{L}$ do sémen foram diluídos em $2 \mathrm{~mL}$ de solução salina de formaldeído para medir a concentração de espermatozoides por $\mathrm{mL}$, utilizando o método hematocitométrico (medido por três diferentes avaliadores) e utilizando o método do espectrofotómetro com comprimento de onda de $550 \mathrm{~nm}$. Não foram detectadas diferenças nos resultados de medição de concentração de espermatozoides por $\mathrm{mL}$ entre os avaliadores medidos pelo método hematocitométrico e espectrofotômetro $(\mathrm{P}>0,05)$. A correlação intraclasse foi alta $(0,9)$, mostrando uma alta replicabilidade entre as medidas das avaliações. Com os resultados do presente experimento, pode-se afirmar que a mensuração realizada pelo espectrofotômetro é confiável, e pode, no futuro, substituir o método hematocitométrico para realizar as mensurações de concentração de espermatozoides no ejaculado de touros jovens da raça Nelore, melhorando e padronizando as técnicas usadas em laboratórios andrologia.

Palavras-chave: Absorbância. Andrologia. Bos indicus. Câmara de Neubauer. Sêmen.

\section{Introduction}

The ejaculate is a biochemically complex fluid comprising secretions from the testes, epididymis, vas deferens, ampoules, vesicle, prostate, and bulbourethral glands. It is composed of proteins, carbohydrates, lipids, minerals, vitamins, and mainly, spermatozoa. Spermatozoa are produced in testes and the physical and morphological aspects of semen reflect testicular functionality (HAFEZ, 2004). Sperm concentration is an important physical aspect as it allows measurement of the number of viable spermatozoa in the ejaculate from young bulls, with the purpose of determining sexual maturity (FRENEAU et al., 2011), thus being important to artificial insemination laboratories for all domestic species (CBRA, 2013).

There are several methods to determine the sperm concentration in ejaculates from domestic animals; among these, the indirect methods involve density determination (densitometry) or light absorption (photometry) and direct methods involve counting of individual cells in a known volume (hematocytometric method) (VIANNA et al., 2007). According to Vianna et al. (2004), the hematocytometric method using the Neubauer chamber is the most reliable technique for measuring sperm concentrations. However, it is not widely used in artificial insemination center as it is timeconsuming and needs several measurements from each sample to obtain precision. Thus, computer analyses are being studied in order to substitute the hematocytometric method in human reproduction laboratories (EGERBERG et al., 2013) and also in fish reproduction laboratories (SORENSEN et al., 2013), with the disadvantage of high cost. Another problem with the hemocytometric method is result variation among evaluators, thus requiring technique standardization among laboratories, as already registered in human reproduction laboratories (WALCZAK-JEDZEJOWSKA et al., 2013; CHRISTMAN et al., 2013).

Sperm densitometry is an indirect method based on the degree of turbidity in the ejaculate (densitometry) and presents advantages in relation to the mentioned techniques, which include lower cost, greater practicality, speed, and precision. However, this technique tends to overestimate the sperm concentration compared to the Neubauer chamber, leading to production of less concentrated doses and consequent fertilization issues (VIANNA et al., 2007).

Spectrophotometry is a technique in which sperm concentration is estimated through the degree of light absorbance in the ejaculate. The device is calibrated against a sample of diluted semen of known sperm concentration previously determined by direct counting (hemocytometry). This method is faster than the hemocytometric method with 
the disadvantage that sperm concentrations can only be evaluated within a strict range of sperm concentrations. This is the most frequent method used in artificial insemination centers (HANSEN et al., 2002). Based on the degree of light absorbance, this technique allows rapid reading and easy handling, and can be used with physiological solutions instead of saline formaldehyde, thus preventing environmental contamination and the health risks to the individuals performing it (CORCINI et al., 2011).

Due to the need for better execution and speed in measuring the sperm concentration of ejaculates in both animal and human reproduction laboratories, this work aimed to compare the results among evaluators using the hemocytometric method and spectrophotometry for measuring sperm concentration in young Nelore bulls.

\section{Materials and Methods}

Ethics Committee: This study was approved by the Ethics Committee of Animal Experimentation (Comitê de Ética em Experimentação Animal) (CEPEEA) under approval no. 26596/2013.

In total, 20 young bulls of the Nelore breed with ages ranging from 18 to 22 months, with a good body score ( 3 on a scale of 5), raised in grazing conditions predominantly with Urochloa decumbens, kept at the Experimental Farm at Universidade Paranaense (UNIPAR) located in the city of Umuarama (PR) during the period of November to December 2013 were used.

The animals were submitted to andrologic testing to assess their reproductive aptitude following the criteria established by the Brazilian College of Animal Reproduction (Colégio Brasileiro de Reprodução Animal - CBRA, 2013). Ejaculates from the animals were collected by the electroejaculation method and subjected to physical and morphological evaluation. Physical properties of the semen samples were analyzed using the following parameters: turbulence, rectilinear progressive sperm motility $(0-100 \%)$, sperm vigor (0-5), and sperm concentration (million spermatozoa/mL).

A drop of semen $(10 \mu \mathrm{L})$ was added onto a previously heated $\left(38^{\circ} \mathrm{C}\right)$ blade on a heating plate for turbulence assessment (movement of spermatozoon mass, ranging from 0-5) using an optical microscope (Nikon Eclipse E-200) at 20x magnification.

Rectilinear progressive sperm motility and sperm vigor were assessed by deposition of $10 \mu \mathrm{L}$ semen on a blade with a coverslip, which was previously heated $\left(38^{\circ} \mathrm{C}\right)$ on a heating plate, and analyzed under an optical microscope (Nikon Eclipse E-200) at 400x magnification (CBRA, 2013).

Sperm morphology was assessed after performing a semen smear and coloring by a panoptical method using optical microscopy at 1000X magnification (under a drop of immersion oil). In total, 200 cells were counted per ejaculate, and sperm defects were measured as percentages according to the classification criteria adopted by the Brazilian College of Animal Reproduction CBRA (2013).

The hematocytometric and spectrophotometric methods were used to measure the sperm concentration. In this experiment, the hematocytometric method using the Neubauer chamber was used as the standard technique owing to its level of precision (Vianna et al., 2007). The sperm concentration per milliliter, using this method, was measured by three different evaluators following the technique described by the Brazilian College of Animal Reproduction (2013). After semen collection, $10 \mu \mathrm{L}$ from the ejaculate was diluted in a $2 \mathrm{~mL}$-saline formaldehyde buffer solution and a small aliquot of this was loaded on the Neubauer chamber. A Nikon (Eclipse E-200) optical microscope with $10 \mathrm{x}$ and 40x lenses was used to perform the sperm count in at least five large squares (comprising 16 small squares), that is, over a total of $5 / 25 \mathrm{~mm}^{2}$, and only spermatozoon heads were taken into consideration. 
After counting both sides of the Neubauer chamber (top and bottom), the average was determined, to be used in the formula for calculating the sperm concentration per $\mathrm{mL}$, according to the College of Animal Reproduction (2013). The following formula was used: $\mathrm{A}(1 / \mathrm{B} \times \mathrm{N} / 25 \times 1 / 10)$, where $\mathrm{A}=$ average spermatozoa count, $\mathrm{B}=$ dilution factor (1:200), $\mathrm{N}=$ large squares counted in the Neubauer chamber (top and bottom, in total 10), and $1 / 10=$ camera height.
The semen samples were also subjected to measurement of optical density in a Micronal spectrophotometer Model B280 at 550nm wavelength. The regression equation that relates the absorbance and sperm concentration measured by the hemocytometric method (Figure 1) was calculated from the measurements taken by one of the evaluators.

Figure 1. Absorbency $(\mathrm{Y})$ as a function of sperm concentration $(\mathrm{X})(\mathrm{millions} / \mathrm{mL})$, and its corresponding regression equation ad determination coefficient $\left(\mathrm{R}^{2}\right)$ for ejaculates from young Nelore bulls.

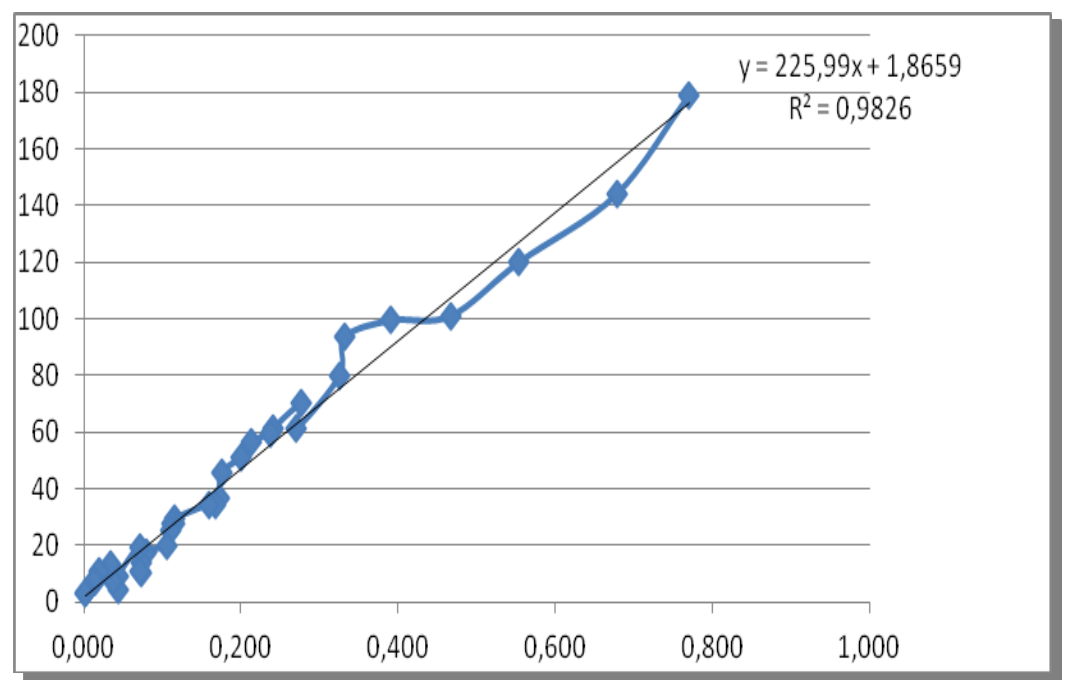

For statistical analysis, the Bioestat 5.3 software was used (AYRES et al., 2007). Means and standard deviations were calculated for all parameters: turbulence, rectilinear progressive sperm motility (0-100\%), sperm vigor (0-5), sperm concentration, and large, minor, and total defects. The Lilliefors test was used to verify the normality of the results for the parameters studied. The non-parametric Kruskal-Wallis test was used to analyze the effects of evaluators on the hematocytometric and spectrophotometric method in the results of sperm concentration measurement. Interclass correlation was used with the purpose of assessing the replicability of sperm concentration results among the evaluators and the spectrophotometer. For all tests, $\mathrm{P}<0.05$ was considered significant.

\section{Results and Discussion}

From the 61 ejaculates collected, 45 (61.65\%) were classified as satisfactory and 28 (38.35\%) as not satisfactory for bulls in a natural breeding scheme (CBRA, 2013). The ejaculates considered unsatisfactory were disqualified because of low rectilinear progressive mobility, which has a minimum value of $70 \%$ for animals in natural breeding schemes (CBRA, 2013). This disqualification index is justified by the fact that the evaluated animals were in the phase of transition to sexual maturity characterized by the physical aspects (rectilinear sperm motility, vigor, and turbulence) and morphological properties of the semen as found in the present experiment (Table 1). 
Table 1. Mean and standard deviation of seminal characteristics from 73 ejaculates from young Nelore bulls.

\begin{tabular}{cccccc}
\hline $\begin{array}{c}\text { Turbulence } \\
(\mathbf{0 - 5 )}\end{array}$ & Motility (\%) & $\begin{array}{c}\text { Vigor } \\
\mathbf{( 0 - 5 )}\end{array}$ & $\begin{array}{c}\text { Major defects } \\
\mathbf{( \% )}\end{array}$ & $\begin{array}{c}\text { Minor defects } \\
\mathbf{( \% )}\end{array}$ & $\begin{array}{c}\text { Total defects } \\
\mathbf{( \% )}\end{array}$ \\
\hline $1.0 \pm 1.2$ & $68 \pm 10.0$ & $3.1 \pm 0.3$ & $7.1 \pm 4.4$ & $2.1 \pm 2.4$ & $8.90 \pm 4.5$ \\
\hline
\end{tabular}

The values obtained, presented low standard deviation and are similar to those described by Brito et al. (2004), Freneau et al. (2006), and Freneau et al. (2010), who also used young Nelore bulls in their experiments.

Sperm concentration is an important parameter in the evaluation of sexual maturity in young bulls (FRENEAU, 2011). Moreover, it is correlated with fertility indexes (WATSON, 2000). Nehring and Rothe (2003) demonstrated that reducing the insulative dose concentration from 15 to 5 million total cells resulted in 3\% to 5\% reduction in fertility. In contrast, Andersson et al. (2004) and Kurykin et al. (2006) observed that according to the individual characteristics of some animals, it is possible to maintain fertility in artificial insemination programs using doses of frozen semen containing 2 million total spermatozoa. Thus, methods that guarantee speed and accuracy in the determination of this parameter allow the optimization of the use of reproducers with high genetic value and the andrological evaluation of a large number of animals in a short period of time.

Manual determination of concentration using the Neubauer chamber is an adapted method of clinical pathology. Although it is widely used in andrology labs, it is a laborious, subjective method with higher coefficients of variation (PALME et al., 2017), thus making it difficult to compare results (BRAZIL et al. 2004).

Spectrophotometers do not directly quantify the sperm but a calibration curve is used to establish the relationship between absorbance and sperm concentration. This relationship is determined empirically by analyzing a series of samples with known concentrations (standards) determined using direct methods such as the hemocytometer, NucleoCounter, or flow cytometer (BRITO et al, 2012). Despite our dependence on direct methods, spectrophotometry provides more accurate results when the equipment is properly calibrated and used correctly. It is therefore the most common method used to evaluate sperm concentration in animal semen processing centers (ANZAR et al., 2009; BRITO et al, 2016). Because it is a standardized method, it becomes the method of choice in research involving semen biotechnology (Purdy and Graham, 2004).

No significant differences $(\mathrm{P}>0.05)$ were detected from the measurements of sperm concentration per $\mathrm{mL}$ among evaluators using hemocytometric method compared to those obtained using a spectrophotometer (Table 2).

Table 2. Means and standard deviation of sperm concentration per $\mathrm{mL}$ ejaculate from young bulls in millions $/ \mathrm{mL}$ measured by hematocytometric and spectrophotometry $(550 \mathrm{nM})$ methods.

\section{Hematocytometric method}

\begin{tabular}{cccccc} 
& & \multicolumn{4}{c}{ Spectrophotometry } \\
\cline { 3 - 6 } Median* & 27 & Evaluator A & Evaluator B & Evaluator C & Means - Evaluators \\
\hline Means & $38.46 \pm 36.34$ & $41.6 \pm 39.3$ & $37.7 \pm 33.1$ & $37.6 \pm 36.7$ & $38.7 \pm 35.2$ \\
\hline
\end{tabular}

*Not significant by the Kruskal-Wallis test $(\mathrm{p}>0.05)$. 
Corroborating the results of this experiment, Eljarah et al. (2013) did not observe differences between the hemocytometer and computer analysis and the spectrophotometry analysis when the hemocytometer was used as the standard method using Holstein bulls. In contrast, Barbosa et al. (2011) showed that spectrophotometry underestimated the results in relation to those obtained by the hemocytometric method and by sperm densitometry.

Conflicting results are expected, as some factors might result in imprecise determination of sperm concentration. In addition to sperm cells, the samples may contain other cell types and soluble organic and inorganic compounds, which may alter the absorbance values obtained in the apparatus. The period between dilution and evaluation should also be standardized because the absorbance may change with time (BRITO et al., 2016). Another factor is the seminal characteristics between different species, as observed by Murgas et al. (2010) and Vianna et al. (2004) when comparing both methods. They concluded that the spectrophotometric method underestimates the concentration values in relation to the hemocytometric method, when evaluating the sperm concentration in swine. The same was described by Silva et al. (2014), when making a similar comparison in the semen of Cateto (Pecari tajacu). These authors suggest that the gel fraction present in the semen of some species such as swine and equine promotes the formation of lumps and changes the reading results obtained by spectrophotometry.
Sperm morphology is also important in this experiment because possible changes in the size of sperm heads and the presence of cytoplasmic droplets in bulls at their early stages of sexual development (HAFEZ, 2004), may result in imprecise determination of the sperm concentration. In this study, this type of

interference was not observed; though the animals were in transition to sexual maturity, the total defects found in the semen were low (Table 1).

The means and standard deviations of sperm concentration per $\mathrm{mL}$ from the three evaluators were $38.7 \pm 35.2$ million spermatozoa (Table 2), which are normal values for young bulls in the final semen maturation stage. The elevated standard deviation in sperm concentrations can be explained by the variation in the physical aspects of bull semen in final seminal maturation stage (HAFEZ, 2004), and also by the individual responses of each animal to electroejaculation stimulus (CBRA, 2013).

Interclass correlation was high (Table 3), indicating that the readings performed were similar to each other with high replicability among the measurements from the three evaluators and the spectrophotometer. Interclass correlation has already been used in research in human andrology laboratories, as shown by Christman et al. (2013) who studied the infertility risks in the adult phase in adolescents, and by Leushuis et al. (2010) who studied the replicability of these techniques used in spermogram of sub-fertile couples.

Table 3. Interclass correlation between sperm concentration per $\mathrm{mL}$ ejaculate from young bulls in millions $/ \mathrm{mL}$ measured by spectrophotometry $(550 \mathrm{nM})$ and hematocytometric methods.

\begin{tabular}{ccccc}
\hline & \multicolumn{4}{c}{ Hematocytometric method } \\
\hline & Evaluator A & Evaluator B & Evaluator C & Means - Evaluators \\
\hline Spectrophotometry & 0.9192 & 0.8711 & 0.9154 & 0.9260 \\
p Value & $<0.0001$ & $<0.0001$ & $<0.0001$ & $<0.0001$ \\
\hline
\end{tabular}


Thus, spectrophotometry proved to be a reliable technique for determining sperm concentrations in young Nelore bulls, with a good linear correlation between the methods compared, under the conditions of this experiment. Its application in the routine of veterinarians working in the field of bovine andrology can generate reports faster and more efficiently, especially at occasions when many bulls are to be examined inside a property.

\section{Conclusion}

The results from the present experiment indicate that sperm concentration measurement performed using the spectrophotometer is reliable, and can substitute the hematocytometric method for performing the sperm concentration measurement in young Nelore bulls in the future, thus improving and standardizing the techniques used in andrology laboratories.

\section{Acknowledgments}

The authors of this paper would like to thank Universidade Paranaense (UNIPAR) for the financial support granted to this research and the team involved in this project for their constant collaboration.

\section{References}

ANDERSSON, M.; TAPONEN, J.; KOSKINEN, E.; DAHLBOM, M. Effect of insemination with doses of 2 or 15 million frozen-thawed spermatozoa and semen deposition site on pregnancy rate in dairy cows. Theriogenology, New York, v. 61, n. 1, p. 1583-1588, 2004.

ANZAR, M.; KROETSCH, T.; BUHR, M. M. Comparison of different methods for assessment of sperm concentration and membrane integrity with bull semen. Journal of Andrology, Philadelphia, v. 30, n. 6, p. 661-668, 2009.

AYRES, M., AYRES JUNIOR, M., AYRES, D. L., SANTOS, A. A. S. Bioestat 5.0 aplicações estatísticas nas áreas das ciências biológicas e médicas. Belém: IDSM, 2007. 364 p.
BARBOSA, C. P.; OLIVEIRA, W. C.; RIBEIROJUNIOR, W. R. Comparação entre as principais técnicas de análise da concentração espermática em exames andrológicos de touros a campo. Publicações em Medicina Veterinária e Zootecnia, Londrina, v. 5, n. 16, p. 1-12, 2011.

BRAZIL, C.; SWAN, S. H.; DROBNIS, E. Z.; LIU, F.; WANG, C.; REDMON, J. B.; OVERSTREET, J. W. Standardized methods for semen evaluation in a multicenter research study. Journal of andrology, Shanghai, v. 25, n. 4, p. 635-644, 2004.

BRITO, L. F.; Althouse, G. C.; AURICH, C.; CHENOWETH, P. J.; EILTS, B. E.; LOVE, C. C.; LUVONI, G. C.; MITCHELL, J. R.; PETER,A.T.; PUGH, D. G.; WABERSKI. D. Andrology laboratory review: evaluation of sperm concentration, Theriogenology, Navasota, v. 85, n. 9, p. 1507-1527, 2016.

BRITO, L. F.; SILVA, A. E.; UNANIAN, M. M.; DODE, M. A.; BARBOSA, R. T.; KASTELIC, J. P. Sexual development in early and late maturing Bos indicus and Bos indicus x Bos taurus crossbred bulls in Brazil. Theriogenology, New York, v. 62, n. 1, p. 1198-1217, 2004.

BRITO, L.; BECKMAN, B.; CARDWELL, B.; DEJARNETTE, J. M.; HUTCHENS, L.; KAYA, A.; KRIEGER, K. E.; LENZ, R.; MITCHELL, J. R.; SIDDIQUI, A. NAAB-CSS semen quality control program minimum guidelines. NAAB Technical Conference on Artifical Insemination and Reproduction, Vancouver, p. 37-41, 2012.

COLÉGIO BRASILEIRO DE REPRODUÇÃO ANIMAL - CBRA. 2013. Manual para exame andrológico e avaliação de sêmen animal. $3^{\text {nd }}$ ed. Belo Horizonte, MG, Brazil. 109 p.

CHRISTMAN, M. S.; KRAFT, K. H.; TASIAN, G. E.; ZDERIC, S. A.; KOLON, T. F. Reproducibility and reliability of semen analysis in youths at risk for infertility. Journal of Urology, Philadelphia, v. 190, n. 2, p. 683-688, 2013.

CORCINI, C. D.; VALELA JUNIOR, A. S.; PIGOZZO, R.; BONGALHARDO, D. C.; THOMAZ JUNIOR, L. Comparison of different solvents in the measurement of sperm concentration of boars in a spectrophotometer. Semina: Ciências Agrárias, Londrina, v. 32, n. 138, p. 1965-1968, 2011.

EGERBERG, D. L.; KJAERULFF, S.; HANSEN, C.; PETERSEN, J. H.; GLENSBJERG, M.; SKAKKEBAEK, N. E.; JORGENSEN, N.; ALMSTRUP, K. Image cytometer method for automated assessment of human spermatozoa concentration. Andrology, Copenhagen, v. 1, n. 4, p. 615-623, 2013. 
ELJARAH, A.; CHANDLER, J.; JENKINS, J. A.; CHENEVERT, J.; ALCANAL, A. Usefulness of hemocytometer as a counting chamber in a computerassisted sperm analyzer (CASA). Animal Reproduction, Belo Horizonte, v. 10, n. 4, p. 708-711, 2013.

FRENEAU, G. E. Aspects of sperm morphology in bulls. Revista Brasileira de Reprodução Animal, Belo Horizonte, v. 35, n. 2, p. 160-170, 2011.

FRENEAU, G. E.; CHENOWETH, P. J.; ELLIS, R.; RUPP, G. Sperm morphology of beef bulls evaluated by two different methods. Animal Reproduction Science, Amsterdam, v. 118, n. 2-4, p. 176-181, 2010.

FRENEAU, G. E.; VALE FILHO, V. R.; MARQUES JUNIOR, A. P.; MARIA, W. S. Puberty in Nelore bulls raised on pasture in Brazil: body, testicular, seminal and soundness capacity index points by Features (ICAP). Arquivo Brasileiro Medicina Veterinária Zootecnia, Belo Horizonte, v. 58, n. 6, p. 1107-1115, 2006.

HAFEZ, E. S. E. Reprodução animal. 7. ed. São Paulo: Manole, 2004. $513 \mathrm{p}$.

HANSEN, C.; CHRISTENSEN, P.; STRYHN, H.; HEDEBOE, A. M.; RODE, M.; BOE-HASEN, G. Validation of the FACS Count AF System for determination of sperm concentration in boar sêmen. Reproduction in Domestic Animals, Berlin, v. 37, n. 1, p. 330-334, 2002.

KURYKIN， J.; JAAKMA， Ü.; WALDMANN，A.; JALAKAS, M.; AIDNIK, M.; MAJAS, L.; PADRIK P. Low semen dose intracornual insemination of cows at fixed time after PGF $2 \alpha$ treatment or at spontaneous estrus. Animal Reproduction Science, Amsterdam, v. 95, n. 1, p. 116-124, 2006.

LEUSHUIS, E.; STEEG, V.; STEEG, J. W. V.; STEURES, P.; REPPING, S.; PATRICK, M. M.; BOSSUYT, P. M. M.; BLANKENSTEIN, M. A.; WILLEM, B.; MOL, B. W.; VEEN, F. V.; VEEN, F. V.; HOMPES, P. G. A. Reproducibility and reliability of repeated semen analyses in male partners of subfertile couples. Fertility and Sterility, Birmingham, v. 94, n. 1, p. 2631-2635, 2010.

MURGAS, L. D. S.; LIMA, D.; ALVARENGA, A. L. N.; ZANGERONIMO, M. G.; OBERLENDER, G.; OLIVEIRA, S. L. Comparative study of different techniques for assessing sperm concentration in boars. Archivos de Zootecnia, Córdoba, v. 59, n. 1, p. 463-466, 2010.
NEHRING, H.; ROTHE, L. Insemination of cryopreserved Bull semen portions with reduced sperm numbers after dilution with two egg yolk-free extenders. In: EUROPEAN A. I. VETS MEETING, 15., 2003, Budapeste. Palestra... Budapeste, 2003. p. 14-23.

PALME, D. L. E.; JOHANNSEN, T. H.; PETERSEN, J. H.; SKAKKEBÆK, N. E.; JUUL, A.; JORGENSEN, N.; ALMSTRUP, K. Validation of image cytometry for sperm concentration measurement: Comparison with manual counting of 4010 human semen samples. Clinica Chimica Acta, Amsterdam, v. 468, p. 114-119, 2017.

PURDY, P. H.; GRAHAM, J. K. Effect of cholesterolloaded cyclodextrin on the cryosurvival of bull sperm. Cryobiology, Houston, v. 48, n. 1, p. 36-45, 2004.

SILVA, A. M.; XAVIER PEIXOTO, G. C.; BRILHANTE BEZERRA, J. A.; SOUZA CASTELO, T. de; ARAUJO SANTOS, E. A.; RODRIGUES SILVA, A. Relações entre a câmara de Neubauer e espectrofotometria utilizadas para a determinação da concentração espermática de catetos (Pecari tajacu). Ciência Rural, Santa Maria, v. 44, n. 8, p. 36-45, 2014.

SORENSEN, S. R.; GALLEGO, V.; PÉREZ, L.; BUTTS, I. A. A. E.; TOMKIEWICZ, J.; ASTURIANO, J. F. Evaluation of methods to determine sperm density for the European eel, Anguilla anguilla. Reproduction in Domestic Animals, Berlin, v. 48, n. 6, p. 936-944, 2013.

VIANNA, W. L.; BRUNO, D. G.; NAMINDOME, A.; CAMPOS ROSSETO, A. C.; BARNABÉ, R. C.; SANT' ANA MORETTI, A. Evaluation of Karras sperm densimeter in relation to the Neubauer counting chamber for sperm concentration measurement in boar sêmen. Reproduction in Domestic Animals, Berlin, v. 42, n. 5, p. 466-470, 2007.

VIANNA, W. L.; BRUNO, D. G.; NAMINDOME, A.; ROSSETO, A. C.; RODRIGUES, P. H. M.; PINESE, M. E.; MORETTI, A. S. Comparative study of the effectiveness of different techniques of measurement of sperm concentration in boars. Revista Brasileira de Zootecnia, Viçosa, v. 33, n. 6, p. 2054-2059, 2004.

WALCZAK-JEDRZEJOWSKA, R.; MARCHLEWSKA, K.; OSZUKOWSKA, E.; FILIPIAK, E.; BERGIER, L.; SLOWIKOWKSKA-HILCZER, J. Semen analysis standardization: is there any problem in Polish laboratories. Asian Journal of Andrology, Shanghai, v. 15, n. 5, p. 616-621, 2013.

WATSON, P. F. The causes of reduced fertility with cryopreserved semen. Animal Reproduction Science, London, v. 60, n. 2, p. 481-492, 2000. 